Elena Guro - James Richie

\title{
Arlekin, the Beggar
}

Characters:

ARLEKIN

TEACHER, 30-something female

CHILDREN, 6 to 7 years old

PASSERBY

COURTESAN

CROWD

RESPECTABLY AGED GENTLEMAN FROM THE AUDIENCE

\section{Scene One}

Over the chimneys, streaks of clouds and smoke across the sky. It is a wet and dismal night. A Saint-Petersburg mansion. In the lordly entrance, stands ARLEKIN in his tights and bells, and he follows the walkers with his eyes.

TEACHER (enters, music is heard in the distance)

ARLEKIN: Let me guide you.

TEACHER: Impudent!

ARLEKIN: Ah, no. Have pity! Please, let me guide you... Just from afar.

TEACHER: Where are the police when you need them?

ARLEKIN (somewhat breaking): My autumn looooove...

TEACHER: Leave me!

ARLEKIN (earnestly, and with misunderstood power): My queen...

TEACHER (is silent) 
ARLEKIN: I love... you are so beautiful! Are you always so beautiful on autumn nights?

TEACHER (as if in a frenzy): Scoff and scoff again! I am a single, thin woman. They pay me twenty rubles... like I'm a cook! I am tired! My voice is hoarse! You listen to me, my voice is hoarse, on my eternally hoarse lips, and I cannot dream of fantasies!

ARLEKIN: Ah, no! It's just, it seems, l've only had one dream... and it is you.

TEACHER (looks back slowly): You have black eyelashes and big eyes on a pale face and children wasting away.

ARLEKIN: I have black eyelashes and big eyes and children wasting away.

TEACHER: You have a sad, expressive face.

ARLEKIN: I have a sad, expressive face.

TEACHER: Your poor lips...

ARLEKIN: My sad lips are nearly always closed. The wind knocks me down.

TEACHER: You have big, sad, expressive eyes, Arlekin.

ARLEKIN: Yes. Do you see it? It's no wonder, my queen. I'm a little bit Jewish. I am, after all, a son of Ahasuerus, the wandering, eternal Jew.

TEACHER: Ah, there it is. That is why you are so quivering and expressive. You are so awful and tortured. On your black and red clothing, I see traces of blood. On your pale arms, there are scratches and bruises. There is fright on your motley coat. Above you, the whole century is scoffing! You shiver. You suffer...

ARLEKIN: Ah, no, my queen. I'm just cold. On the earth, there is cold, but there are also joyful carnivals. And so many songs! And I have had so many women that I am going bald... just a little. And now, I am just chilly under my paper cap. You see, it is hereditary. My papa was very chilly, and so I am cursed with cold in your Petersburg.

TEACHER (turns away with disgust)

ARLEKIN (in pursuit): I am cold! I am so cold, and the wind knocks me down! 
TEACHER (speeds up her steps)

ARLEKIN (fades out)

A foggy, empty street. The solitary voice of ARLEKIN.

ARLEKIN: In the sleepless mirrors of Alcazar, full of colorful madness, spins a sick sleepless devil who does not open his lips. And when he takes off his cap, laughing at the ceiling, the glow of the chandeliers reflecting on his bald head.

(The fog clears. The PASSERBY appears, near ARLEKIN.)

ARLEKIN: Let me guide you...

PASSERBY: Guide a man? Yes, you have lost all shame. I will shout for the police now! You wretch! You are making me run now, and I am short of breath!

ARLEKIN: I am the most out of breath. But you will not make me run so soon! I must guide everyone on this stormy night. And this one doesn't even find me fantastical?

PASSERBY: You... hooligan! Police! (ARLEKIN and the PASSERBY disappear)

ARLEKIN (reappears, singing a canzone)

Here are the lights dancing on thin legs

I tear off the starry beads

Strange dreams grow on the frost

Strange, icy flowers grow on the glasses

Two swallows are stuck on a bench. They are chilly birds.

The Italian singer is wrapped up in the sable's throat.

The lamp once asked me:

Where did you come from, pale man?

Your eyes are sunken, poor Arlekin!

She birthed me on a Southern night

To the ringing of bells 
To the sound of mindless wineglasses

To the laughter of fools

They brought me, wrapped up, to the sable

From the hot countries, where Minona Aplesinnie vomits flowers

Little Minona, you dance!

Arlekin's fantasy

We dance to the drums

Of the strict gentleman

Disowning me with wine

To the sound of the cups

And then

Erected in triumph

On the scaffold of the booth

Little Minona, you dance

The Colombina dream

Dance, kiss

Arlekin's fantasy!

Ah, happy carnival, pale faces

Ah, icicles shed tears

And when I was alone

The night sighed

Ah, homeless child, Arlekin

Tender child

You came to us from afar

To this snowy country

Glaciers hang you

Snowflakes mock you

On your eyebrows

Ah... 
Curtain

\section{Scene Two}

Night. The scene presents a nursery. The curtain comes up. There is a lamp burning on a table. There is a night light. Two children are in their beds.

CHILD ONE: Let's say goodbye to the night. Soon it will go away. Well, considering that soon we will fall asleep.

CHILD TWO: Today, the curtain isn't down. I can see the street.

ARLEKIN (notices, with his face pressed against the glass. He's kindlier and has put on weight now.)

CHILD TWO: Our old Arlekin... Look!

CHILD ONE: You came, Arlekin! Let's play!

ARLEKIN: Let's. Shhhhhh, I came, only smoke. (Puts a finger to his lips). Hush, Hush. You've got a Jew on your roof.

CHILD ONE: His nose doesn't look broken off at all.

CHILD TWO: God healed his nose in the Kingdom of Heaven. Maybe he wants to come to the nursery. Arlekin, won't you come through the window?

ARLEKIN: I'm very good here. I have the whole windowsill to myself. I've brought something. (He reaches into his bag and withdraws many paper chickens.)

CHILDREN: Ka-ka-re-ku! Ka-ka-re-ku!

ARLEKIN: Ka-ka-re-ku! I was far, far away.

CHILD ONE: We thought that you were under the dresser, but you were thrown out. Isn't it scary outside, Arlekin?

ARLEKIN: No. The lanterns wink at me. The gas burners dance like my bells.

CHILD TWO: You have a snowflake melting on your nose. Aren't you cold? 
ARLEKIN: Before, I was chilly, but now I'm warm here.

CHILD ONE: How I want to let Arlekin in through the window! Shouldn't we open the window just in case?

CHILD TWO: I'm a little scared.

(The MOTHER's footsteps are heard. She enters.)

CHILD ONE: Mamma, Mamma! Arlekin came over! There he is! Standing there in the window! We would very much like to call him in to warm up!

(The MOTHER steps with the lamp in her arms over to the window. The pale face of ARLEKIN is pressed up against the glass, expressing suffering. He disappears.)

CHILD TWO: Aww. He got scared and ran off! Arlekin, can you believe it? Mamma, you really scared him! How rotten!

Curtain

\section{Scene Three}

Outside. Crowd. ARLEKIN.

ARLEKIN: Guide me. I'm lost.

COURTESAN: Getting lost doesn't mean dancing in the middle of the street!

ARLEKIN (puffing up): Maybe, I dance, and then I get lost, my little kitten.

(In a different tone) I got lost. It's very hard to find one's way in these dark streets. Ah, here. I can show you some tricks.

(He takes out a handful of heavenly stars from his pocket and throws them in the air.)

They will fly now, like swallows, near the sky!

(The stars fall on the ground and lie there.)

CROWD (laughs)

ARLEKIN: (shyly smiling)

VOICE FROM THE CROWD: You're obsolete, ARLEKIN! 
ARLEKIN: Today and tomorrow, you are eating cutlets and peas. I am cold. (He turns away.)

If you want, l'll dance for you!

PASSERBY: Never. Kindly, never.

VOICE FROM THE CROWD: Dance! Go on, Arlekin! Give us a show!

ARLEKIN: I can't. I am chilly.

CROWD (laughs)

VOICE FROM THE CROWD: This rope runner, running away from the circus! A vagrant dog! A curious figure! Rather pathetic!

ARLEKIN: You're making me bald.

VOICE FROM THE CROWD: His paleness is really depraved! Such paleness is shameful!

ARLEKIN: Walk on down the road! I am frozen still. I am sick!

CROWD (laughs)

ARLEKIN: I am sorry, my most respectable audience. While dancing, I lost a boot off my foot! I realize that this is very indecent. Please forgive me.

VOICE OF A WOMAN (shrieking): Jackanape! He is fooling us! His boots are intact.

ARLEKIN: Help me, please, to find my boot. I humbly ask you. (Reciting oblivious.)

I daydreamed of Minona. She is a picture. She comes to the call of Arlekin.

(Someone from the audience cannot take it any longer and gets on stage with ARLEKIN.)

RESPECTABLY AGED GENTLEMAN FROM THE AUDIENCE: Allow me. Listen to me, dear fellow. Stop. Understand, that you, with your difference, are here on a most ordinary evening, right on the main street, and that you are out of place.

ARLEKIN (disappears completely)

Curtain 


\section{(c) (i) (9)}

Creative Commons Attribution-NonCommercial-NoDerivatives 4.0 International License 